2. To: (Receiving organization)

SNF K-Basin Projects

5. Proj./Prog./Dept./Div.:
SNF/K-Basin/MCO

5. Proj./Prog./Dept./Div.:
SNF/K-Basin/MCO

8. Originator Remarks:

This EDT releases Test PIan WHC-SD-SNF-TP-026, REV. 0

11. Receiver Remarks:

\begin{tabular}{l} 
3. From: (originating organization) \\
Engineering Testing \\
Laboratory \\
6. Cog. Engr.: \\
P. V. Meeuwsen \\
\hline
\end{tabular}

3. From: (originating organization)

Engineering Testing

6. cog. Engr.:

P. V. Meeuwsen
11. Receiver Remarks:

\section{EDT 601038}

4. Related EDT No.:

N/A

7. Purchase Order No.:

$N / A$

9. Equip./Component No.:

$N / A$

10. System/Bldg./Facility:

$N / A$

12. Major Assm. Dwg. No.: $N / A$

13. Permit/Permit Application No.: $N / A$

14. Required Response Date: $\mathrm{N} / \mathrm{A}$

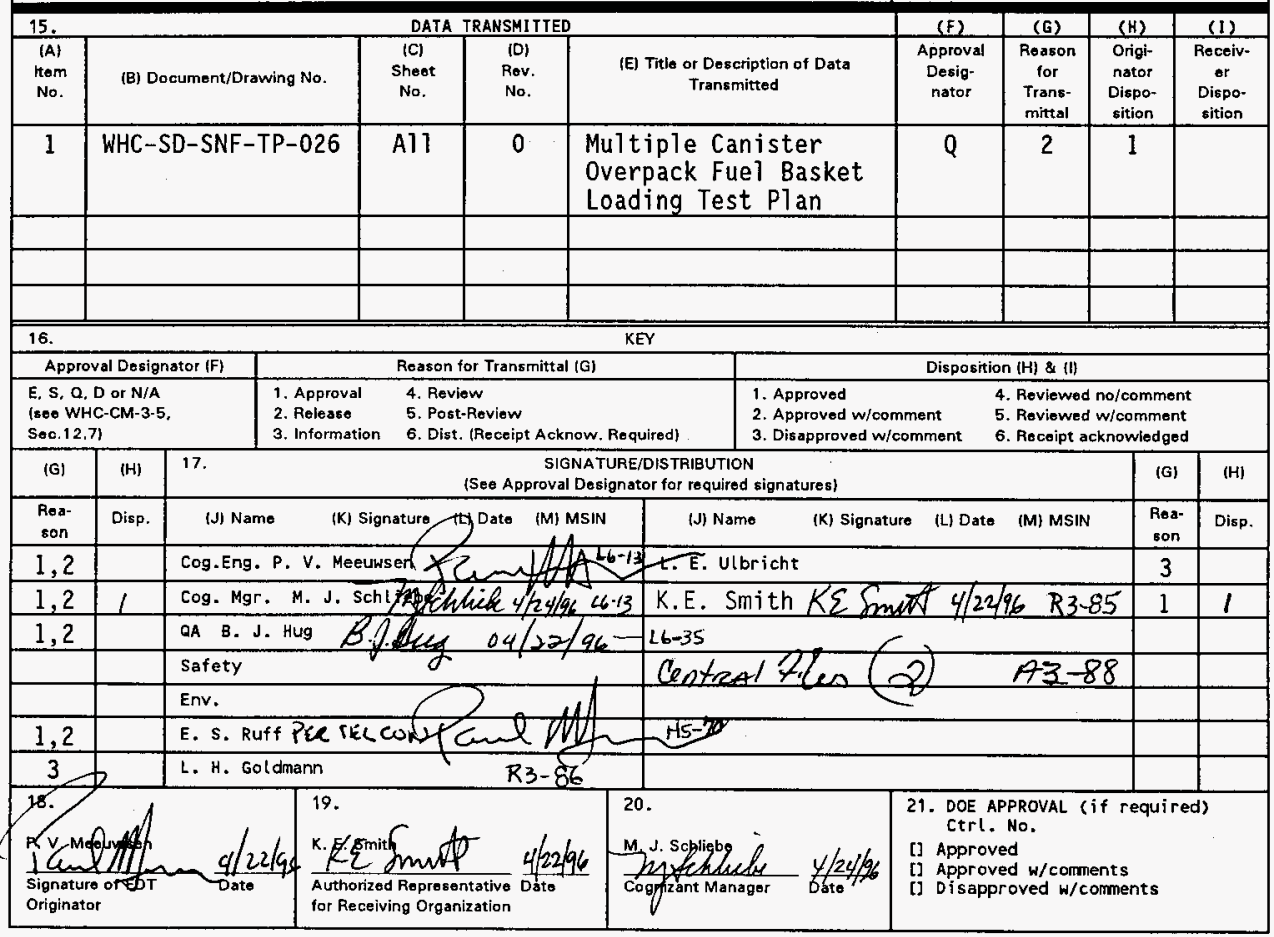




\title{
Multiple Canister Overpack Fuel Basket Loading Test Plan
}

\author{
P. V. Meeuwsen \\ WHC, Richland, WA 99352 \\ U.S. Department of Energy Contract DE-AC06-87RL10930 \\ EDT/ECN: 601038 UC: \\ Org Code: 8A100 Charge Code: LE024 \\ B\&R Code: EW3135040 Total Pages: 27
}

Key Words: Multiple Canister Overpack

Abstract: This test plan, documents the procedure required to test the Multiple Canister Overpack design in regards to the loading of the fuel baskets.

TRADEMARK DISCLAIMER. Reference herein to any specific comercial product, process, or service by trade name, trademark, manufacturer, or otherwise, does not necessarily constitute or imply its endorsement, recommendation, or favoring by the United States Government or any agency thereof or its contractors or subcontractors.

Printed in the United States of America. To obtain copies of this document, contact: WHC/BCS Document Control Services, P.O. Box 1970, Mailstop H6-08, Richland WA 99352, Phone (509) 372-2420; Fax (509) 376-4989.
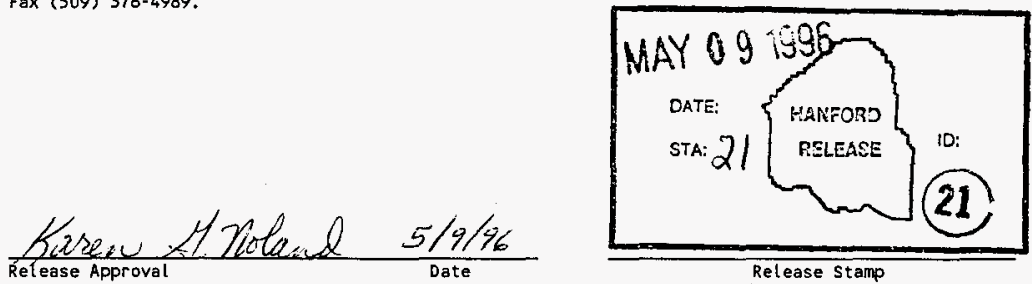

Release Stamp

\section{Approved for Public Release}


WHC-SD-SNF-TP-026

Rev. 0

MULTIPLE CANISTER OVERPACK FUEL BASKET LOADING TEST PLAN

WHC-SD-SNF-TP-026 REV 0

APRIL 15, 1996

Paul Meeuwsen

Engineering Testing 
WHC-SD-SNF-TP-026

REV 0

PAGE 2 OF 10

TABLE OF CONTENTS

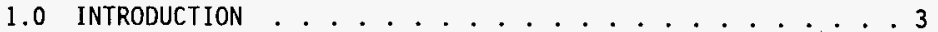

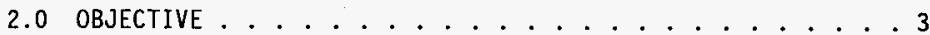

3.0 SCOPE $\ldots \ldots \ldots \ldots \ldots \ldots$

4.0 TEST DESCRIPTION . . . . . . . . . 5

4.1 TEST FACILITIES, LOCATION $\ldots \ldots$

4.2 TEST EQUIPMENT, TOOLS ............ 5

4.3 TEST DATA, DOCUMENTATION ............... 6

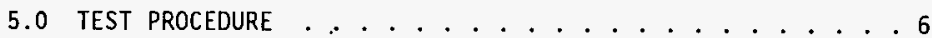

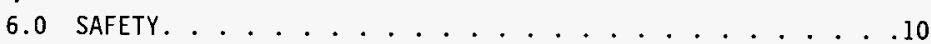

7.0 QUALITY ASSURANCE .................. 10

APPENDIX A - FUEL REMOVAL MAP

APPENDIX B - DATA SHEETS

APPENDIX C - EQUIPMENT CALIBRATION DATA SHEET 
WHC-SD-SNF-TP-026

REV 0

PAGE 3 OF 10

\section{MULTIPLE CANISTER OVERPACK FUEL BASKET LOADING TEST PLAN WHC-SD-SNF-TP-026 REV 0}

\subsection{INTRODUCTION}

This Test Plan will document the procedure required to develop the parameters under which a prototype fuel basket may be loaded into a Multiple Canister overpack (MCO) without damaging the MCO or the basket.

For detailed description of the MCO refer to document WHC-S-0426, "Performance Specification for the Spent Nuclear Fuel Multi-Canister Overpack", prepared by Westinghouse Hanford Company, Richland, WA 99352

The tests found in this plan will be performed in the $K$ Basin Mockup (KBMU) located in the 305 Building.

\subsection{OBJECTIVE}

The objective of this testing is to verify the design of the MCO and fuel baskets in regards to loading of the fuel baskets into the MCO.

\subsection{SCOPE}

The scope of this Test Plan is only a limited portion of the overall test activities associated with the MCO. Other test plans will follow.

The ability for the fuel basket grapple to remotely grasp, hoist, lower, and release a basket will not be tested at this time.

Tests will be performed using MK-IV, MK-IA and SPR fuel baskets. MK-IV and MK-1A baskets will be tested using dummy MK-IV fuel elements (SK-1-0027-1). SPR baskets will be tested with lead bricks or other weights.

A $2 / 3$ length mockup $M C O$ has been fabricated using 24 inch A53 carbon stee 1 pipe with a nominal wall thickness of $1 / 2$ inch. The pipe is ten feet long and supported by a six legged framework with adjustable feet.

Tests 1-IV, 1-1A, and 1-SPR will be performed in the 305 highbay, all other tests will take place in the KBMU.

The following tests will be conducted:

$125 \%$ LOAD TESTS

1-IV. MK-IV BASKET LOAD TEST: Load test of MK-IV basket, grapple adapter and pole hook to $125 \%$ of expected weight of a fully loaded basket. 
WHC-SD-SNF-TP-026

REV 0

PAGE 4 OF 10

1-1A. MK-1A BASKET LOAD TEST: Load test of MK-1V basket, grapple adapter and pole hook to $125 \%$ of expected weight of a fully loaded basket.

1-SPR. SPR BASKET LOAD TEST: Load test of SPR basket, grapple adapter and pole hook to $125 \%$ of expected weight of a fully loaded basket.

\section{LOADING BALANCED BASKET INTO MCO}

2-IV. LOADING BALANCED MK-IV BASKET INTO MCO: Loading of a fully loaded (54 elements) MK-IV basket into a MCO.

2-1A. LOADING BALANCED MK-1A BASKET INTO MCO: Loading of a fully loaded (48 elements) MK-1A basket into a MCO.

2-SPR. LOADING BALANCED SPR BASKET INTO MCO: Loading a SPR basket with equivalent weight of 114 elements basket into a MCO.

LOADING BALANCED BASKET INTO MCO WITH LOAD GUIDE FUNNEL

2a-IV. LOADING BALANCED MK-IV BASKET INTO MCO WITH LOAD GUIDE FUNNEL: Loading of a fully loaded (54 elements) MK-IV basket into a MCO with the aid of a load guide funnel (SK-2-300388).

2a-1A. LOADING BALANCED MK-1A BASKET INTO MCO WITH LOAD GUIDE FUNNEL: Loading of a fully loaded (48 elements) MK-1A basket into a MCO with the aid of a load guide funnel.

2a-SPR. LOADING BALANCED SPR BASKET INTO MCO WITH LOAD GUIDE FUNNEL: Loading a SPR basket with equivalent weight of 114 elements into a MCO with the aid of a load guide funnel.

\section{OFF BALANCE LOADING OF BASKET INTO MCO}

3-IV. OFF BALANCE LOADING OF MK-IV FUEL BASKET: Deve1 op a maximum MK-IV fuel basket off balance envelope that may be loaded into a MCO.

3-1A. OFF BALANCE LOADING OF MK-IA FUEL BASKET: Develop a maximum MK-1A fuel basket off balance envelope that may be loaded into a MCO.

3-SPR. OFF BALANCE LOADING OF SPR FUEL BASKET: Develop a maximum SPR fue] basket off balance envelope that may be loaded into a MCO.

OFF BALANCE LOADING OF FUEL BASKET WITH USE OF MCO LOAD GUIDE FUNNEL

3a-IV. OFF BALANCE LOADING OF MK-IV FUEL BASKET WITH USE OF A LOAD GUIDE FUNNEL: Develop a maximum MK-IV fuel basket off balance 
WHC-SD-SNF-TP-026

REV 0

PAGE 5 OF 10

envè Tope that may be loaded into a MCO with the aid of a load guide funnel.

3a-1A. OFF BALANCE LOADING OF MK-1A FUEL BASKET WITH USE OF A LOAD GUIDE FUNNEL: Develop a maximum MK-1A fuel basket off balance envelope that may be loaded into a MCO with the aid of a load guide funne?.

3a-SPR. OFF BALANCE LOADING OF SPR FUEL BASKET WITH THE USE OF A LOAD GUIDE FUNNEL: Develop a maximum SPR fuel basket off balance envelope that may be loaded into a MCO with the aid of load guide funnel.

\section{MULTIPLE OFF CENTER BASKET LOADING}

4-IV. MULTIPLE OFF CENTER MK-IV FUEL BASKETS LOADING: Tests the ability of the MCO prototype to accept off center loaded MK-IV fuel baskets without damage to the MCO or basket. Also tests the nesting features of the MK-IV basket.

4-1A. MULTIPLE OFF CENTER MK-1A FUEL BASKETS LOADING: Tests the ability of the MCO prototype to accept off center loaded MK-1A fuel baskets without damage to the MCO or basket. Also tests the nesting features of the MK-1A basket.

4a-SPR. MULTIPLE OFF CENTER SPR FUEL BASKET LOADING: Tests the ability of the MCO prototype to accept off center loaded SPR fuel baskets without damage to the MCO or basket. Also tests the nesting features of the SPR basket.

\subsection{TEST DESCRIPTION}

\subsection{TEST FACILITIES, PERSONMEL}

Testing will be conducted in the 305 building by Engineering Testing Laboratory personnel. Tests that are required to be conducted underwater wil] be carried out in the KBMU (SK-3-300632). Other tests will be performed in the 305 building highbay. A two ton monorail or a five ton bridge crane will be used for the tests outlined in this test plan.

\subsection{TEST EQUIPMENT, TOOLS}

The following equipment/tools are required to conduct the tests:

$2 / 3$ length prototype MCO

(2) Mark IV prototype fuel baskets (SK-2-300375)

(2) Mark IA prototype fuel baskets (SK-1-80208)

(2) SPR prototype fuel baskets (SK-2-300376) 
WHC-SD-SNF-TP-026

REV 0

PAGE 6 OF 10

(54) dummy fuel èlements (SK-1-80027-1)

(2) 1/4 turn grapple adapters (SK-2-30077)

Modified pole hook (SK-2-30038)

Load guide funnel (SK-2-300388)

Digital level (accuracy: $+1-.1$ degree)

Dynamometer (accuracy: +/- 12 pounds)

General shop hoisting and rigging equipment

Underwater camera/video recorder

Lead or other weight

Equipment calibration data will be collected on the calibration data sheet found as appendix $C$ of this test plan.

\subsection{TEST DATA, DOCUMENTATION}

Test data shall be gathered on the data sheet found as appendix $B$ of this test plan.

Still photos and/or a video will be taken to document the significant portions the tests. The photos and/or video tape will be maintained on file in the 305 building. Copies will be made available upon request by contacting WHC Engineering Testing Laboratory.

After testing, components and test articles will be packaged, labeled and shipped to a Hanford Site convenience storage location per the direction of the MCO Testing Coordinator.

WHC Engineering Testing will issue a final report within two weeks after the conclusion of all tests described in this plan. The Test Report will be released as a supporting document.

\subsection{TEST PROCEDURE}

Test 1-IV, 1-1A, and 1-SPR must be performed first. All other test may be performed in any order that is convenient.

$$
125 \% \text { LOAD TEST }
$$

\section{1-IV. MK-IV BASKET LOAD TEST}

I. Load MK-IV fuel basket (SK-2-300375) with 54 dummy fuel elements.

2. Using pole hook and grapple adapter, raise basket one foot or less. Record dynamometer reading on Appendix B data sheets. Record dynamometer calibration data on sheets in Appendix $C$. 
WHC-SD-SNF-TP-026

REV 0

PAGE 7 OF 10

3. Using lead bricks or other weights, load basket to $125 \%$ of weight of loaded basket found above. Record weight on Data Sheet.

4. Using pole hook and grapple adapter, raise basket loaded to $125 \%$ one foot or less. Hold for five minutes. Visually inspect for damage. Record damage (if any) on data sheets.

1-1A. MK-1A BASKET LOAD TEST

Repeat test 1-IV using MK-1A fuel baskets (SK-1-80208) and 48 dummy fuel elements.

1-SPR. SPR BASKET LOAD TEST

Repeat test 1-IV using SPR fuel baskets (SK-300376) and lead bricks or other weight.

LOADING BALANCED BASKETS INTO MCO

2-IV. LOADING BALANCED MK-IV BASKET INTO MCO

1. Load MK-IV fuel basket with 54 dummy fuel elements.

2. $\mathrm{Place} 2 / 3 \mathrm{MCO}$ prototype in KBMU. Plumb MCO using adjustable feet on MCO spider.

3. Without using loading guide, load Fuel Basket in to MCO. Start recording time when Fuel Basket is approximately one foot above MCO. End time when fuel basket bottoms in MCO. If time is greater than ten minutes, abort test and continue with tests below. Record time and comments on data sheets.

\section{2-1A. LOADING BALANCED MK-IA BASKET INTO MCO}

1. Load MK-1A fuel basket with 48 dummy fuel elements.

2. Place $2 / 3$ MCO prototype in KBMU. Plumb MCO using adjustable feet on MCO spider.

3. Without using loading guide, load Fuel Basket in to MCO. Start recording time when Fuel Basket is approximately one foot above MCO. End time when fuel basket bottoms in MCO. If time is greater than ten minutes, abort test and continue with tests below. Record time and comments on data sheets. 
WHC-SD-SNF-TP-026

REV 0

PAGE 8 OF 10

2-SPR. LOADING BALANCED SPR BASKET INTO MCO

1. Load SPR fuel basket with a balanced load of lead bricks or other weights equal to the weight of a fully loaded basket.

2. Place $2 / 3$ MCO prototype in KBMU. PTumb MCO using adjustable feet on MCO spider.

3. With basket hanging from grapple and pole hook, load Fuel Basket in to MCO. Start recording time when Fuel Basket is approximately one foot above MCO. End time when fuel basket bottoms in MCO. If time is greater than ten minutes, abort test and continue with tests below. Record time and comments on data sheets.

\section{LOADING BALANCED BASKETS INTO MCO WITH GUIDE}

2a-IV. LOADING BALANCED MK-IV BASKET INTO MCO WITH GUIDE.

Repeat test 2-IV using loading guide. Record data on data sheets.

2a-1A. LOADING BALANCED MK-IA BASKET INTO MCO WITH GUIDE.

Repeat test 2-1A using loading guide. Record data on data sheets.

2a-SPR. LOADING BALANCED SPR BASKET INTO MCO WITH GUIDE.

Repeat test 2-SPR using loading guide. Record data on data sheets.

\section{OFF BALANCE LOADING OF FUEL BASKET}

\section{3-IV. OFF BALANCE LOADING MK-IV BASKET INTO MCO.}

1. Load MK-IV fuel basket with 54 dummy fuel elements.

2. Raise loaded fuel basket approximately two feet. Using digital level, record plumb measurement at two places 180 degrees apart. Record data on data sheets. Record digital level calibration data on calibration data sheets.

3. Using fuel removal map found as appendix $A$, remove dummy fuel element jdentified as 1 . Repeat step 2 above.

4. Continue removing dummy fuel in order outlined on fuel removal map until 20 fuel pieces are removed or the basket reaches 20 degrees out of $p 7$ umb. Record two level measurements for each fuel piece removed on data sheets.

5. Reload basket with fuel elements. 
WHC-SD-SNF-TP-026

REV 0

PAGE 9 OF 10

6. Without using loading guide. Load Fuel basket with one element removed into MCO. Start recording cycle time when Fuel Basket is approximately one foot above $M C O$. End cycle time when of Fuel Basket bottoms in MCO. If time is greater than ten minutes, abort test. Record time and comments to data sheets.

7. Continue removing dummy fuel and loading basket into MCO unti] 20 fuel pieces are removed, the basket reaches 20 degrees out of plumb, or it takes greater than 10 minutes to load Fuel Basket in MCO. Record comments and times for each fuel piece removed to data sheets.

3-1A. OFF BALANCED LOADING MK-1A BASKET INTO MCO.

Repeat test $3-I V$. Record data on data sheets.

3-SPR. OFF BALANCED LOADING SPR BASKET INTO MCO.

Repeat test 2-SPR. Place lead bricks or other weights into SPR basket. Position weight in basket to closely simulate out of plumb values found in test 3-IV above. Record data on data sheets.

OFF BALANCE LOADING OF FUEL BASKET WITH USE OF MCO LOAD GUIDE 3a-IV. OFF BALANCED LOADING MK-IV BASKET INTO. MCO WITH USE OF LOAD GUIDE. Repeat test 3-IV. Record data on data sheets.

3a-1A. OFF BALANCED LOADING MK-1A BASKET INTO MCO WITH USE OF LOAD GUIDE. Repeat test 3-1A. Record data on data sheets.

3a-SPR. OFF BALANCED LOADING MK-1A BASKET INTO MCO WITH USE OF LOAD GUIDE. Repeat test 3-SPR. Record data on data sheets.

4-IV. MULTIPLE OFF CENTER MK-IV FUEL BASKETS LOADING IN MCO.

1. Place $2 / 3$ MCO prototype in KBMU. Plumb MCO using adjustable feet on MCO spider. 
WHC-SD-SNF-TP-026

REV 0

PAGE 10 OF 10

2. Place .009-.020 Plastigage (Part Number PY-1) at six expected basket to basket contact points on top of MK-1V basket. The Plastigage shall be taped down (tape placed in noncontact areas).

3. Place empty MK-IV fuel basket from step 2 into MCO. When basket is approximately $1 / 2$ way down prototype MCO, pull with hand pressure so basket slides down side of MCO. Note direction of pulling force.

4. Place a fully loaded MK-IV basket into MCO. When top of basket is below top of MCO, pull with hand pressure 180 degrees from direction noted in step 3. continue lowering basket until it rests on top of first basket.

5. Remove baskets. Note location and take measurements of Plastigage to three decimal places. Record data on data sheets.

4-1A. MULTIPLE OFF CENTER MK-IA FUEL BASKETS LOADING IN MCO.

Repeat test 4-IV using MK-IA baskets. Record data on data sheet.

4a-SPR. MULTIPLE OFF CENTER SPR FUEL BASKET LOADING IN MCO.

Repeat test 4-IV using SPR fuel baskets and lead bricks or other weights inplace of MK-IV dummy fuel. Record data on data sheets

\subsection{SAFETY}

The safety class for this work is 3 . All work shall be performed in accordance with the "Safety Manual" (WHC-CM-1-10), "Hanford Site Hoisting and Rigging Manua 1" (DOE-RL-92-36), "Standard Engineering Practices" (WHC-CM-6-1), and the "305 Facility Administration Manual" (WHC-IP-1155).

There are no radiation hazards associated with this work.

\subsection{QUALITY ASSURANCE}

Testing will be conducted under the Westinghouse Quality Assurance requirements as specified in the Quality Assurance Manual (WHC-CM-4-2).

Quality Assurance will be notified of the proposed testing schedule and will witness testing activities as they feel necessary. Nebraska.

1 Plastigage is a registered trademark of Perfect Circle, Hastings, 
APPENDIX A

FUEL REMOVAL MAPS

WHC-SD-SNF-TP-026

Rev. 0

(sheet I of 3)

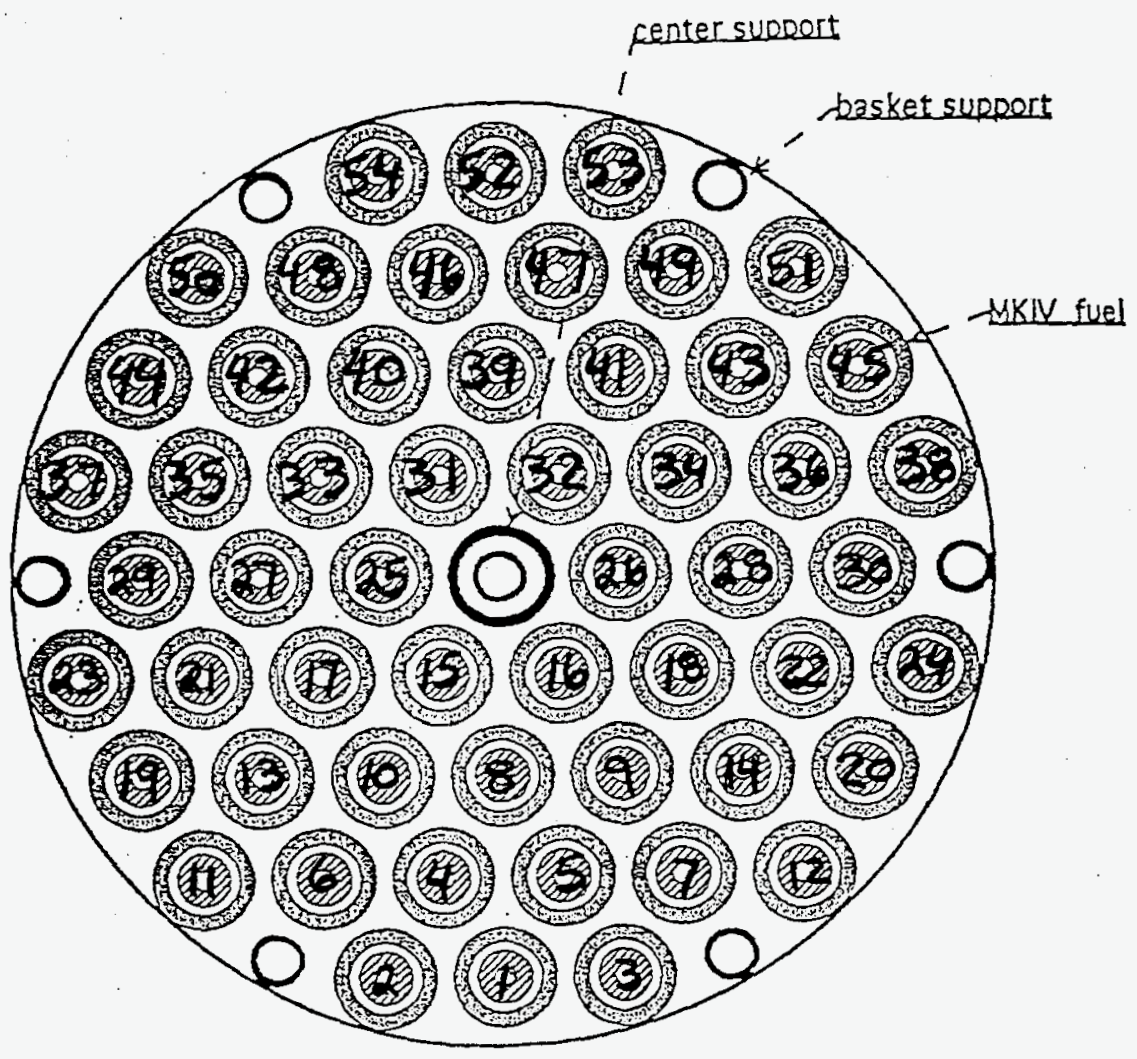

MK-IV FUEL

REMOVAL MAP

A-1 RCT COPP ANALIEL 
FUEL REMOVAL MAPS WHC-SD-SNF-TP-026
ReV. 0

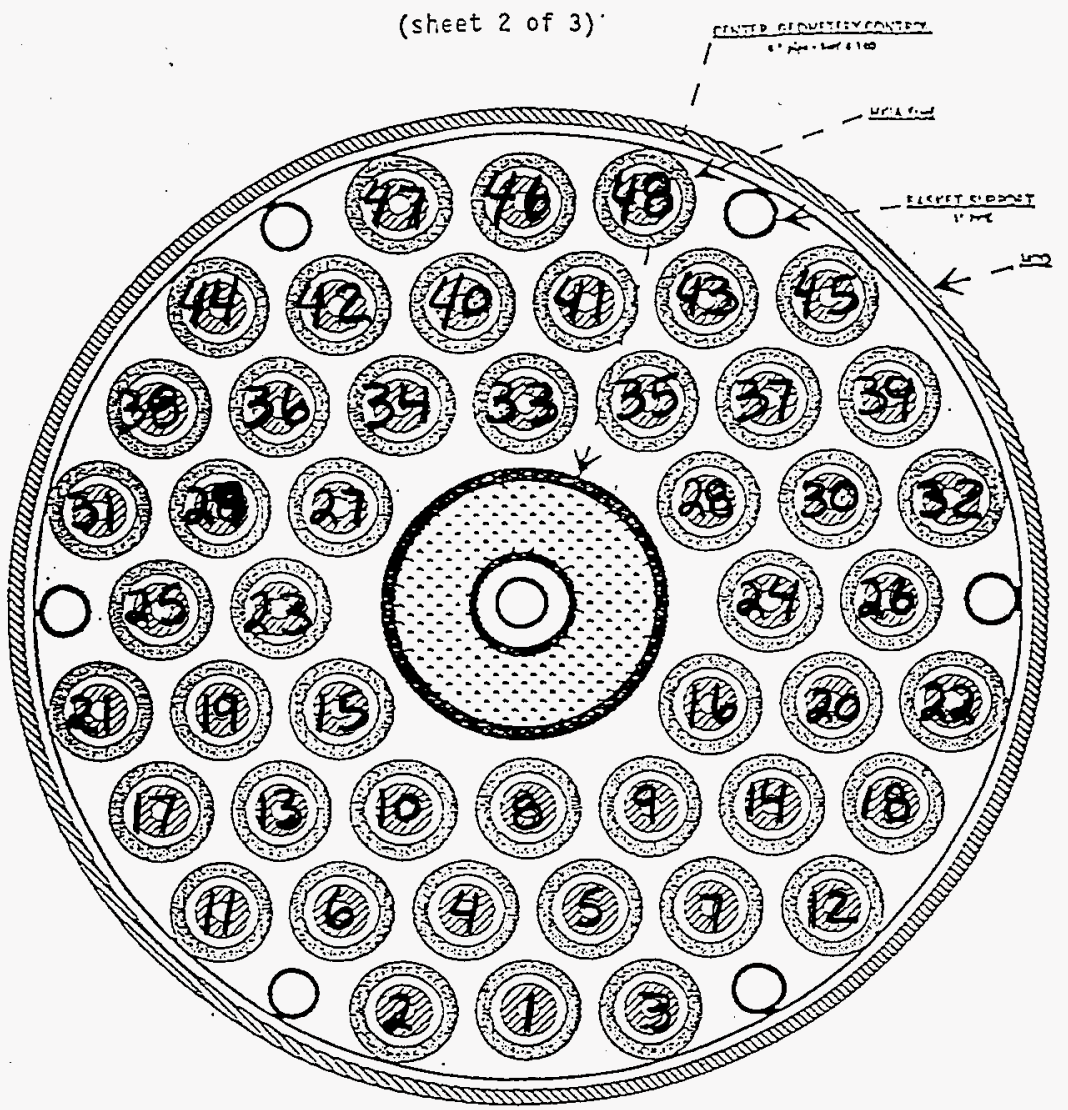

MK-IA FUEL

REMOVAL MAP 


\section{FUEL REMOVAL MAPS}

(sheet 3 of 3 )

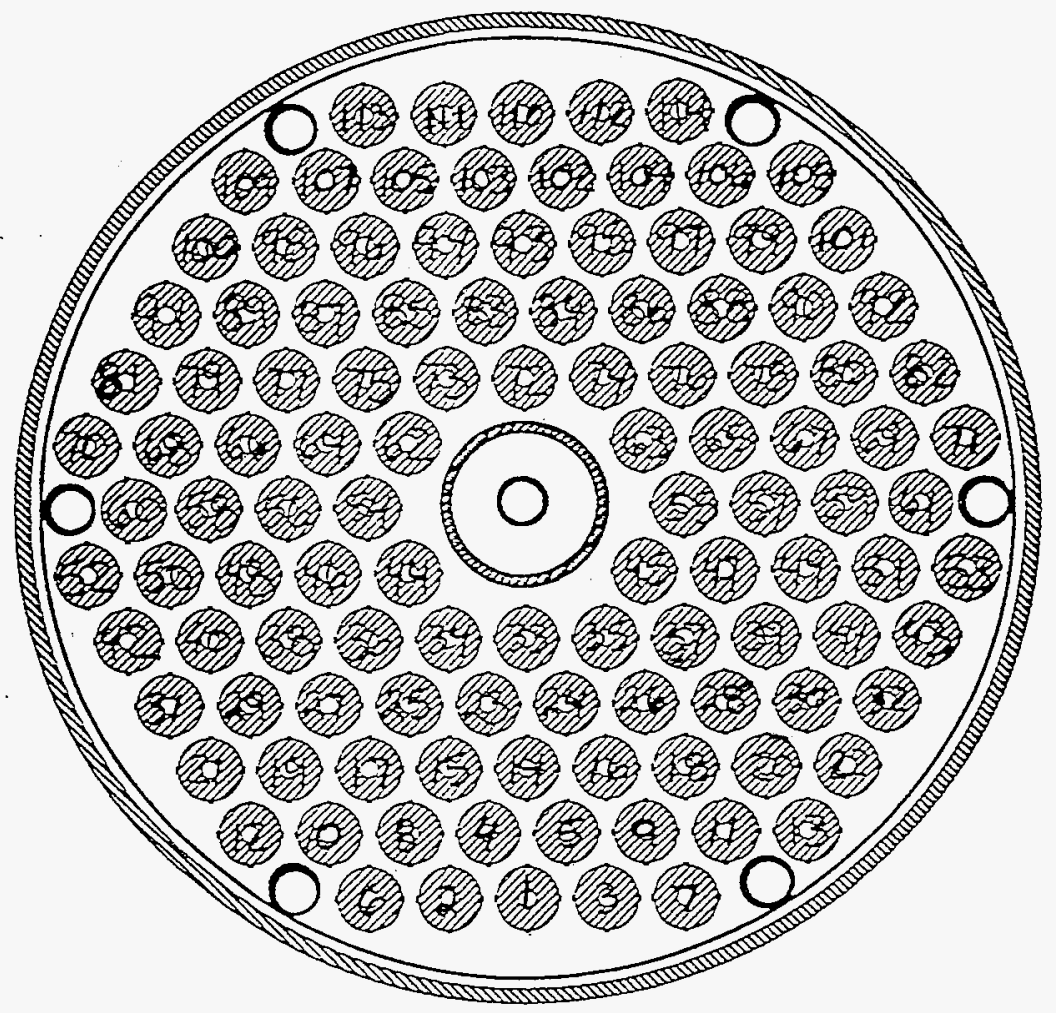

SPR FUEL

REMOVAL MAP 


$$
\text { APPENDIX B - DATA SHEETS }
$$

\section{TEST 1-IV MK-IV BASKET LOAD TEST}

MK-IV Basket (SK-2-300375)

MK-IV Dummy fue1 (SK-1-80027-1)

Weight of fully loaded basket Pounds

Kilograms

$125 \%$ of fully loaded basket Pounds Kilograms PASS / FAIL

Damage/comments

\section{TEST 1-1A MK-1A BASKET LOAD TEST}

MK-1A Basket (SK-1-80208)

MK-IV Dummy fuel (SK-1-80027-1)

Weight of fully loaded basket Pounds Kilograms

$125 \%$ of fully loaded basket Pounds Kilograms PASS / FAIL

Damage/comments

\section{TEST 1-SPR SPR BASKET LOAD TEST}

SPR Basket (SK-300376)

Weight of fully loaded basket Pounds Kilograms

$125 \%$ of fully loaded basket Pounds Kilograms PASS / FAIL Damage/comments 
TEST 2-IV LOADING BALANCED MK-IV FUEL BASKET INTO MCO (no load guiderev. 0

MK-IV Basket (SK-2-300375)

MK-IV Dummy Fuel (SK-1-80027-1)

Loaded Fuel Basket one foot above MCO - start time

Loaded Fuel Basket bottoms in MCO - end time

Elapsed time (if greater than $10 \mathrm{~min}$, abort test)

Comments

TEST 2-1A LOADING BALANCED MK-1A FUEL BASKET INTO MCO (no load guide)

MK-1A Basket (SK-1-80208)

MK-IV Dummy Fue1 (SK-1-80027-1)

Loaded Fuel Basket one foot above MCO - start time

Loaded Fuel Basket bottoms in MCO - end time

Elapsed time (if greater than $10 \mathrm{~min}$, abort test)

Comments

TEST 2-SPR LOADING BALANCED SPR FUEL BASKET INTO MCO (no load guide)

SPR Basket (SK-300376)

Loaded Fuel Basket one foot above MCO - start time

Loaded Fuel Basket bottoms in MCO - end time

Elapsed time (if greater than $10 \mathrm{~min}$, abort test)

Comments 
TEST 2a-IV LOADING BALANCED MK-IV FUEL BASKETS INTO MCO WITH GUIDE REV 0

MK-IV Basket (SK-300375)

MK-IV Dummy Fuel (SK-1-80027-1)

Load Guide funnel (SK-300388)

Loaded Fuel Basket one foot above MCO - start time

Loaded Fuel Basket bottoms in MCO - end time

Elapsed time (if greater than $10 \mathrm{~min}$, abort test)

Comments

\section{TEST 2a-1A MCO LOAD TEST WITH GUIDE}

MK-1A Basket (SK-1-80208)

MK-IV Dummy Fue 1 (SK-1-80027-1)

Load Guide funnel (SK-300388)

Loaded Fuel Basket one foot above MCO - start time

Loaded Fuel Basket bottoms in MCO - end time

Elapsed time (if greater than $10 \mathrm{~min}$, abort test)

Comments

TEST 2a-SPR FUEL BASKET MCO LOAD TEST WITH GUIDE

SPR Basket (SK-300376)

Load Guide funnel (SK-300388)

Loaded Fuel Basket one foot above MCO - start time

Loaded Fuel Basket bottoms in MCO - end time

Elapsed time (if greater than $10 \mathrm{~min}$, abort test)

Comments 
TEST 3-IV OFF BALANCE LOADING MK-IV FUEL BASKET (no load guide)

MK-IV Basket (SK-2-300375)

MK-IV Dummy Fuel Element (SK-1-80027-1)

Fuel Element(s) Removed

$$
1
$$

2

3

4

5

6

7

8

9

10

11

12

13

14

15

16

17

18

19

20
Level Readings
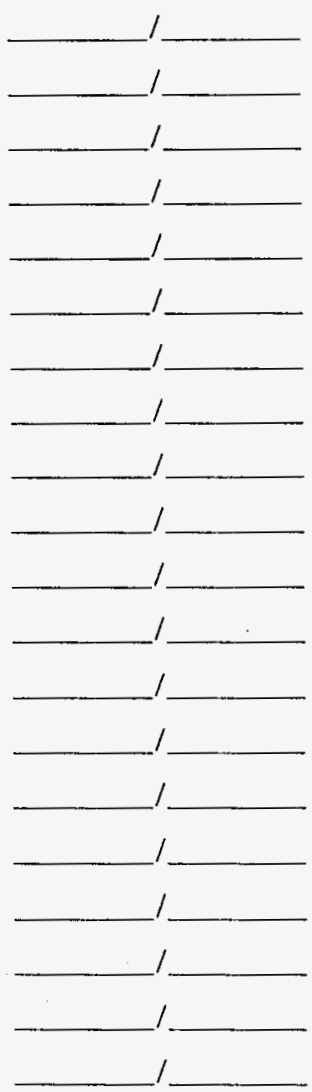

Start/End/Cycle time
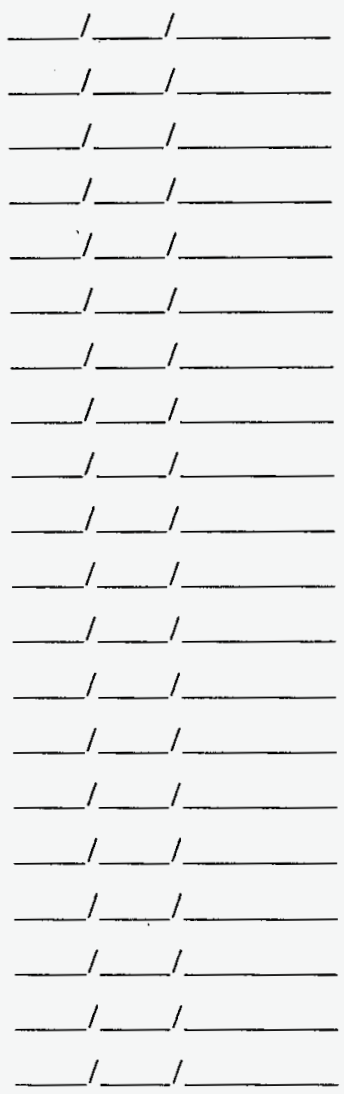

Comments 
WHC-SD-SNF-TP-026

Rev. 0

TEST 3-1A OFF BALANCE LOADING MK-1A FUEL BASKET (no load guide)

MK-1A Basket (5K-1-80208)

MK-IV Dummy Fuel Element (SK-1-80027-1)

FueT Element(s) Removed

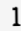

2

3

4

5

6

7

8

9

10

11

12

13

14

15

16

17

18

19

20

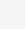

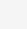

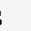

9

10

1

12

5

6

Level Readings
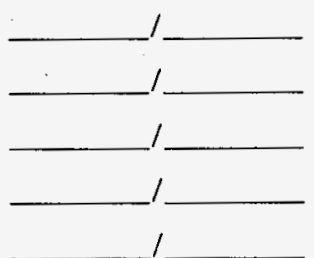

Comments
Start/End/Cycle time

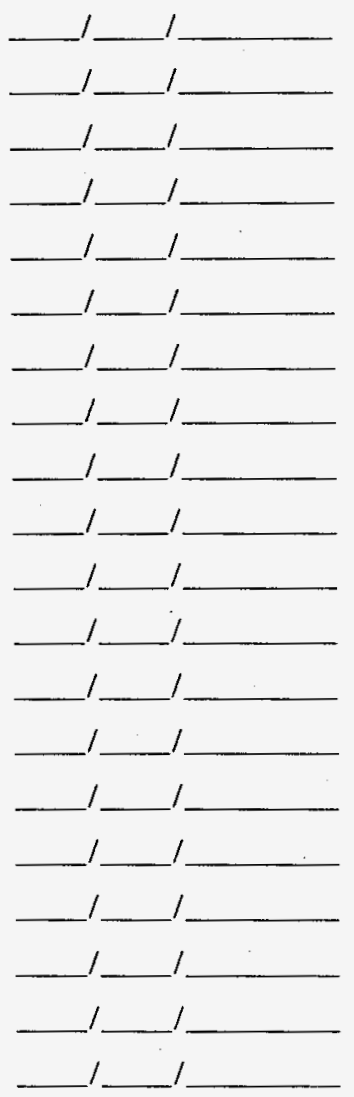


WHC-SD-SNF-TP-026

Rev. 0

TEST 3-SPR OFF BALANCE LOADING SPR FUEL BASKET (no load guide)

MK-IV Basket (SK-2-300375)

MK-IV Dummy Fuel Element (SK-1-80027-1)

Fuel Element(s) Removed

Level Readings

Start/End/Cycle time

1

2

3

4

5

6

7

8

9

10

11

12

13

14

15

16

17

18

19

20

Comments
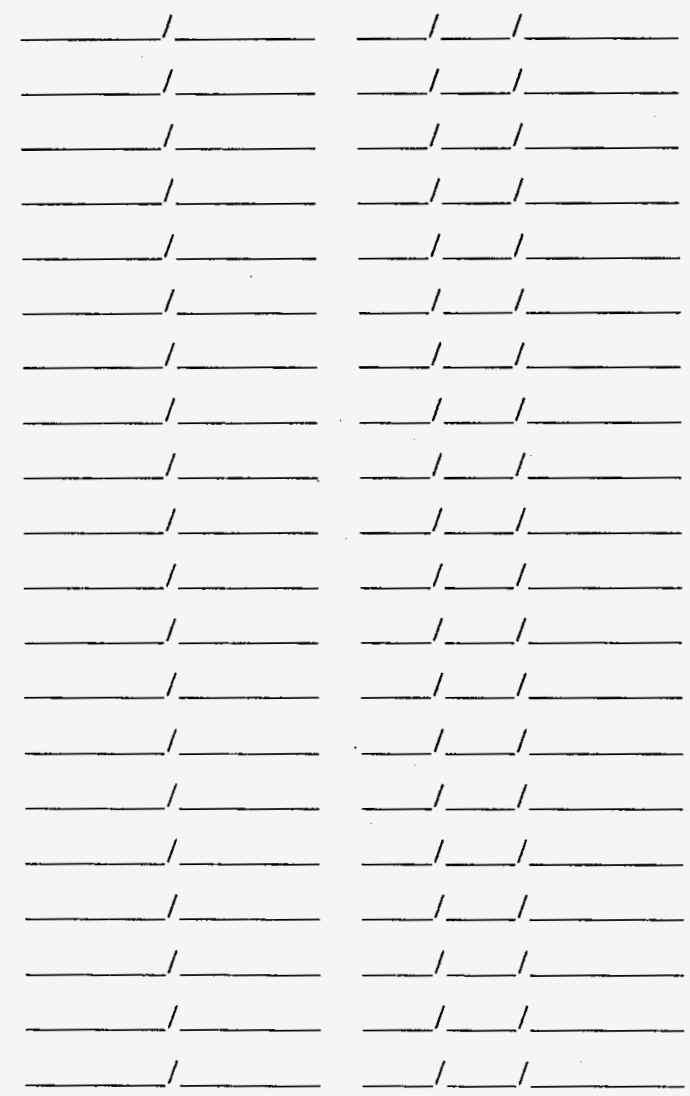
TEST 3a-IV OFF BALANCE LOADING MK-IV FUEL BASKET WITH LOAD GUIDE REV. 0

MK-IV Basket (SK-2-300375)

MK-IV Dummy Fuel Element (SK-1-80027-1)

Fuel Element(s) Removed

1

2

3

4

5

6

7

8

9

10

11

12

13

14

15

16

17

18

19

20
Level Readings
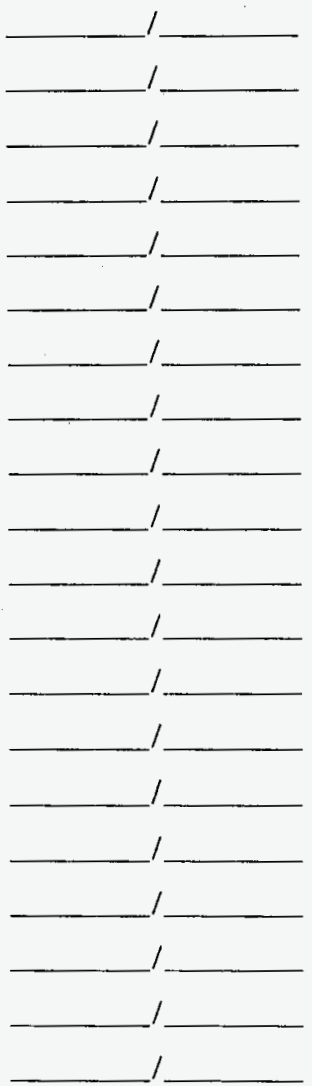

Start/End/Cycle time
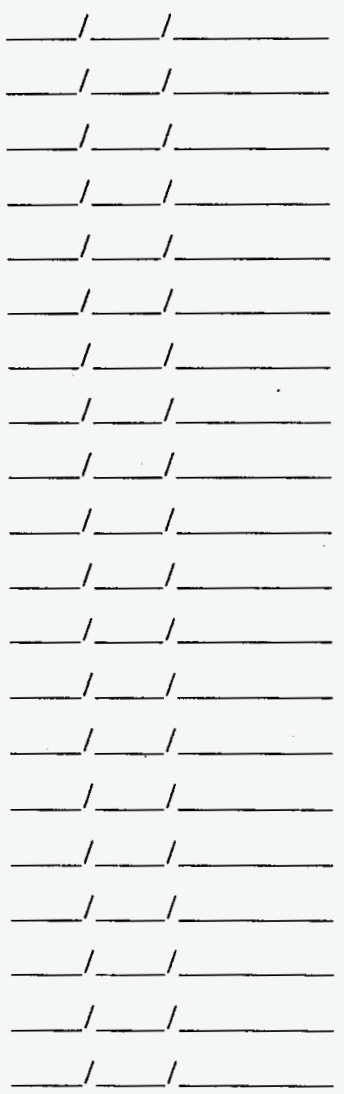

Comments 
TEST 3a-1A OFF BALANCE LOADING MK-IA FUEL BASKET WITH LOAD GUIDE Rev. 0

MK-1A Basket (SK-1-80208)

MK-IV Dummy Fuel Element (SK-1-80027-1)

Fuel Element(s) Removed

1

2

3

4

5

6

7

8

9

10

11

12

13

14

15

16

17

18

19

20

5
Level Readings
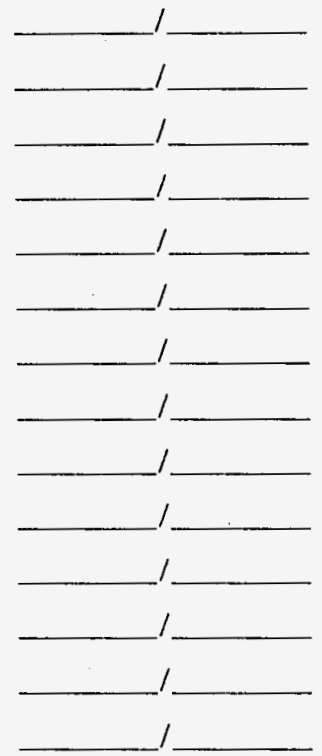

Comments
Start/End/Cycle time
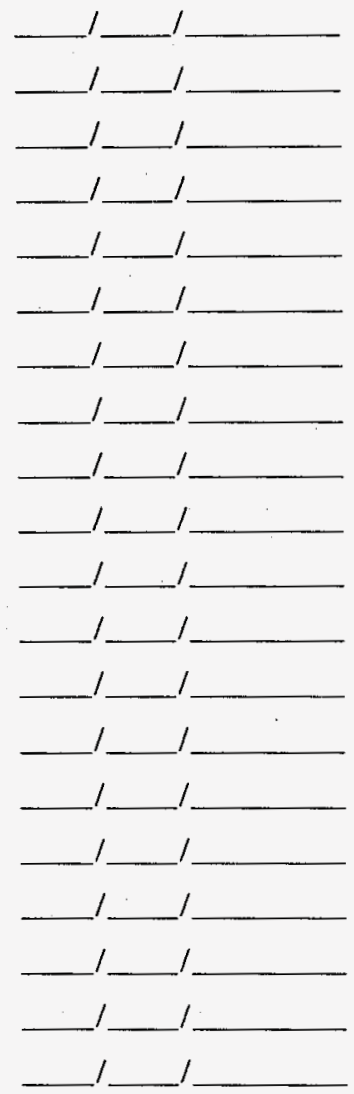
TEST 3a-SPR OFF BALANCE LOADING SPR FUEL BASKET WITH LOAD GUIDE ReV. 0

SPR Basket (SK-2-300376)

MK-IV Dummy Fuel Element (SK-1-80027-1)

Fue] Element(s) Removed

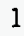

2

3

4

5

6

7

8

9

10

11

12

13

14

15

16

17

18

19

20
Level Readings
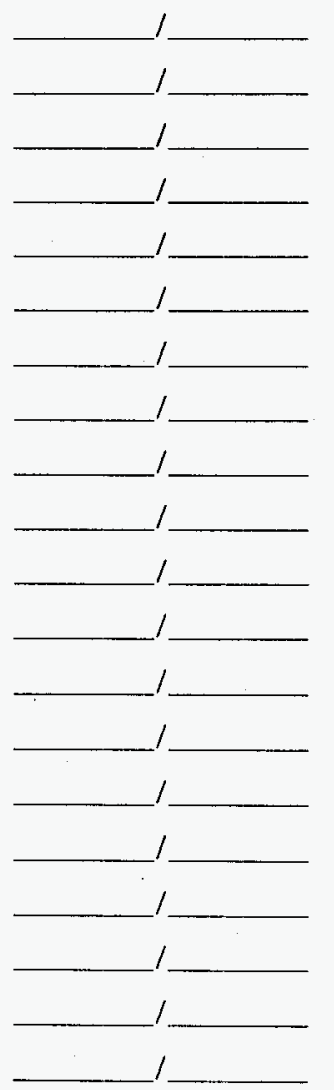

Start/End/Cycle time
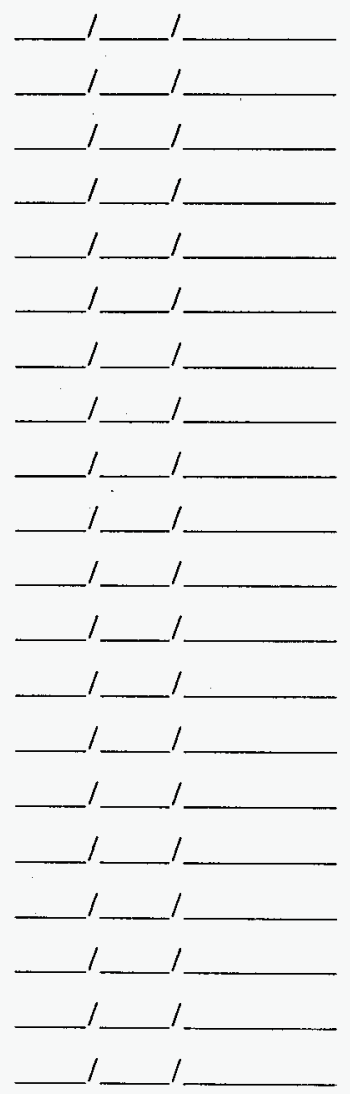

Comments 
WHC-SD-SNF-TP-026

\section{4-IV MULTIPLE OFF CENTER MK-IV FUEL BASKET LOADING IN MCO ReV. 0}

MK-IV Basket (SK-2-300375)

Draw sketch to note location of Plastigage.

Thickness measurements of Plastigage.

1. inches/

millimeters

2. inches/ millimeters

3. inches/ millimeters

4. inches/ millimeters

5. inches/ millimeters

6. inches/ millimeters 


\section{4-1A MULTIPLE OFF CENTER MK-1A FUEL BASKET LOADING IN MCO}

MK-1A Basket (SK-1-80208)

Draw sketch to note location of Plastigage.

Thickness measurements of Plastigage.

1. inches/ millimeters

2. inches/ millimeters

3. inches/ millimeters

4. inches/ millimeters

5. inches/ millimeters

6. inches/ millimeters 


\section{4-SPR MULTIPLE OFF CENTER SPR FUEL BASKET LOADING IN MCO}

SPR Basket (SK-2-300376)

Draw sketch to note location of Plastigage.

Thickness measurements of Plastigage.

1. inches/ millimeters

2. inches/ millimeters

3. inches/ millimeters

4. inches/ millimeters

5. inches/ millimeters

6. inches/ millimeters 


$$
\begin{array}{rr}
\text { WHC-SD-SNF-TP-026 } \\
\text { APPENDIX C - EQUIPMENT CALIBRATION DATA SHEET } & \text { ReV. } 0
\end{array}
$$

EQUIPMENT

STANDARDS CODE NUMBER

RECALL DATE

STANDARDS CODE NUMBER

RECALL DATE

EQUIPMENT

EQUIPMENT

RECALL DATE

STANDARDS CODE NUMBER

EQUIPMENT

RECALL DATE

STANDARDS CODE NUMBER 